\section{Listening to patients}

\author{
LINDA GASK
}

Every person who has experienced a severe depression has his own sad, awful tale to tell, his own mess to live through.

So says Elizabeth Wurtzel at the end of Prozac Nation (1995) her story of depression and drug misuse which has achieved a certain cult status on both sides of the Atlantic. But what can the recent crop of confessional accounts of personal struggles with mental illness tell us about the experience of suffering? The only real alternative would be to interview a random sample of patients, and some survey data of this type do exist. The 'People First' study by MIND (Rogers et al, 1993) was criticised at the time of its publication for being 'unrepresentative'. However, although the recent study by the Mental Health Foundation, Knowing Our Own Minds (1997), aimed, successfully, to reach a broader sample of patients, it lacks the immediacy of the earlier study which employed in-depth interviewing, rather than questionnaires, to gather data.

People who write books about their experience are also unrepresentative but, to borrow an argument from Rogers and her colleagues, this should not detract from the recognition that they too can provide a 'legitimate version of reality'. Fictionalised accounts (such as The Bell Jar by Sylvia Plath and Janet Frame's Faces in the Water) have been joined by autobiographies such as Frame's own An Angel at my Table (1984). They can provide considerable insight into, for example, the nature of profound depression as described by William Styron in Darkness Visible (1991) and Tim Lott in The Scent of Dried Roses (1996). In An Unquiet Mind (1996) Kay Redfield Jamison courageously revealed her long struggle with manic-depressive illness, as Stuart Sutherland did earlier in Breakdown (1987, republished in 1995). Sheila MacLeod provided what is still the most powerful account of anorexia nervosa (1981), a theme also echoed in Drinking: A Love Story (Knapp, 1996), a sometimes sentimental story of alcohol dependence which mimics the sensational style of Prozac Nation. Although one could question whether American books are relevant to this country, what all of these books have in common is their unflinching honesty, often punctuated by bleak humour. Both Styron and Lott describe the flawed logic by which they arrived at a decision to end their lives, though neither actually made an attempt to do so. Frame describes waking up after taking an unsuccessful overdose. Jamison, who took a massive overdose of lithium together with an anti-emetic to ensure its effectiveness, dryly observes that "in psychiatric circles you earn the right, if you kill yourself, to be considered a 'successful' suicide. This is a success one can live without".

\section{WHAT WE CAN LEARN FROM PERSONAL ACCOUNTS}

Perhaps it is no coincidence that mood disorders and neurotic illness predominate in these accounts. The impact of a deteriorating psychotic illness may impair the creative process, although this did not prevent Ruth Fainlight's brother Harry from continuing to write poetry. She has written a touching memoir of his struggle with psychotic illness (reprinted in Dunn et al, 1996). In contrast, Janet Frame (1984) described the experience of being diagnosed as schizophrenic, receiving over 200 applications of unmodified ECT and narrowly avoiding 'normalisation' by leucotomy, having put on "my schizophrenic fancy dress" for the young lecturer who was the only person to show interest in her.

In addition to helping us to understand by describing, perhaps more eloquently than some other of our patients could, the nature of the experience, these accounts have other things to offer. First, they can help us to understand the experience of being a patient. Not just the awful and inappropriate incarceration of young people on psychiatric wards here, in the USA and New
Zealand in the past (Frame, 1984; Read, 1989; Kaysen, 1995), but the culture of modern British in-patient life. Sutherland (1995) describes the tedium, the trauma generated by suicide attempts, the fellowship with co-residents, the support of certain professionals, the disappointment at not having more contact with psychologists and psychiatrists and taking part in "that piece of psychiatric ceremonial known as a ward round .... it reminded me of the end of a play when the cast appear to receive their applause". His descriptions of being a recipient of well-meaning but simplistic attempts at group and marital therapy, complete with trite and predictable interpretations, should be read by all mental health professionals in training. Tim Lott's description of his first out-patient appointment could be farcical if it were not so horribly plausible. Having admitted (to the reader) that he is irritated that he merits only a trainee he is determined to prove "that I am not a cretin" only to later overhear, through the door behind which trainee and consultant are discussing his case, the consultant reassure the trainee "the intelligent ones are the worst. You have to be firm" (Lott, 1996).

Second, such accounts can remind us of the stigma of mental illness. Both Stuart Sutherland and Kay Jamison comment on how they were discouraged by colleagues from going into print about their experiences for fear that this would damage their career. Tim Lott is forthright about the attitudes of society: "Even if you recover ...there are plenty of people, both professional and lay, who will insist that you were not (ill), that it is all down to you. And if you are a depressive, a part of you will be all too ready to agree". At the time that his book was published, William Styron was forced to defend his right to have been 'ill' during an interview on BBC television.

Third, they can help us to understand the paradoxical 'safety' of certain, often familiar, symptoms and behaviours. "Faced with the family anguish, I made my usual escape, the route now perfected" writes Frame. Knapp describes her escape into drinking as a "fear of life", and Macleod talks of anorexia as "the only strategy open to me in order to preserve any sort of identity".

\section{TAKING THE TABLETS}

These personal accounts can also provide more insight into why people find it so hard 
to accept pharmacological treatment. It is hard to believe that one's "filigree thoughts and beliefs can be reduced to a simple malfunction of neurotransmitters" (Lott) and more comforting to believe that "our depressions were more complicated and existentially based than they actually were" comments Jamison, who adds "antidepressants might be indicted for psychiatric patients, for those of weaker stock, but not for us". Jamison's description of her struggle with lithium is made all the more poignant because of her status as a highly respected researcher and writer in the field. She talks of the pain of accepting, by taking lithium, the loss of the positive attributes of hypomania and of having recognised that no pills could help her deal with the problem of not wanting to take pills.

Although many of the writers clearly benefited ultimately from taking tablets, they are not all positive about the way in which treatment was provided. Styron says of his psychiatrist "his platitudes were not Christian but, almost as ineffective, dicta drawn straight from the pages of The Diagnostic and Statistical Manual of the American Psychiatric Association". He is critical of the "breezy optimism" of much of the available literature which, he feels, promises quick remedy "if only the suitable antidepressant can be found". This poses a dilemma for the clinician-how to be realistically optimistic about the outcome of most episodes of depression while not inducing a sense of failure in those who do not make a fast recovery. Most of the writers see a need for more combination of medication with psychotherapy, though not of the strictly analytic kind. Jamison concludes that her own experience of being a patient has made her aware of how psychotherapy "could keep one alive long enough to have a chance at getting well; and how it could help one to learn to reconcile the resentments at taking medication with the terrible consequences of not taking it". These thoughts are echoed by Wurtzel (1995) who recognised that although she needed Prozac and lithium to stay well, she also needed a therapist "to

LINDA GASK, FRCPsych, Royal Preston Hospital, and National Primary Care Research and Development Centre, University of Manchester

Correspondence: Linda Gask, Academic Unit, Royal Preston Hospital, Sharoe Green Lane, Preston PR2 9 HT

(First received 8 January 1997, final revision 24 March 1997, accepted 27 March 1997)

help me learn to be a grown up, to show me how to live in a world where the phone company doesn't care that you're too depressed to pay the phone bill". She goes through several therapists in this book before finding one who is able to engage her successfully.

\section{A SHARED UNDERSTANDING}

Finally, the search, in each of these accounts, for a cause for all this suffering may also say something important. It raises the question of how we explain research in meaningful terms if it is not to lose its relevance to those people who we aim, ultimately, to help. Although all the authors writing about their experience of mood disorders can accept the biological nature of the illness, they, as we, are fascinated by the interplay between genetics, family life, personality and life events. Tim Lott, drawing on Durkheim, attempts to understand both his own depression and that of his mother, which tragically resulted in suicide, in terms of the loss of an apparently safe, suburban image of post-war 'Little England'. He describes how his mother tried in vain to cling to this as he struggled to leave it behind: "(depression) is the illness of identity ... of those who do not know where they fit, who lose faith in the myths they have so painstakingly created for themselves". Nevertheless, most people who suffer from depression do not have unusual problems about identity. Jamison is unflinching in her belief in the importance of biomedical research, but she is well placed to understand the relevance and promise of current developments. To many of our patients, our faith in biomedical explanations and cures may seem misplaced. In seeking to explain and communicate our increasing knowledge about the biological basis of mental illness we must continue to listen, to respond in terms that can be understood and not forget, as Sutherland concludes:

My mood swings were almost certainly biochemically caused, but this does not mean that the feelings that accompanied them were not real. The jealousy, the anxiety, the fears, the boredom, the self-hatred, the despair, even the spasms of elation - all were real.

\section{REFERENCES}

Dunn, S., Morrison, B. \& Roberts, M. (eds) (1996) Mind Readings: Writers' Journeys Through Mental Stotes. London: MIND and Minerva.

Frame, J. (1984) An Angel at my Table. London: The Women's Press.

Jamison, K. R. (1996) An Unquiet Mind: A Memoir of Moods and Madness. London: Picador.

Kaysen, S. (1995) Girl, Interrupted. London: Virago.

Knapp, C. (1996) Drinking: A Love Story, London: Quartet. Lott, T. (1996) The Scent of Dried Roses. London: Viking.

MacLeod, S. (1981) The Art of Storvation. London: Virago.

Mental Health Foundation (1997) Knowing Our Own Minds: A Survey of how People in Emotional Distress take Control of their Lives. London: MHF.

Read, S. (1989) Only for a Fortnight: My life in a Locked Ward. London: Bloomsbury.

Rogers, A., Pilgrim, D. \& Lacey, R. (1993) Experiencing Psychiatry: Users' Views of Services. London: MIND and Macmillan.

Styron, W. (1991) Dorkness Visible. London: Picador

Suthertand, S. (1995) Breakdown: a Personal Crisis and a Medical Dilemma (updated edn). Oxford: Oxford University Press

Wurtzel, E. (1995) Prozac Nation: Young and Depressed in America - A Memoir. London: Quartet. 